\title{
Intermittent Shock
}

National Cancer Institute

\section{Source}

National Cancer Institute. Intermittent Shock. NCI Thesaurus. Code C63064.

Problem associated with the failure to deliver shock for a limited period of time, following which the item recovers its ability to perform its required function without being subjected to any external corrective action. Note: such as failure is often recurrent. 